\title{
Anthony R. Dicks (1936-2018): An Appreciation
}

\author{
Michael Palmer
}

Professor Anthony Dicks, who died aged 82 in early November 2018, was a world expert in Chinese law. He drew on years of research, primarily using Chinese-language written sources, for both professional and academic analysis of important aspects of law in China. ${ }^{1}$ He did so first as a Current World Affairs Fellow (1963-1968) based mainly in Hong Kong, and later while practising at the Bar in Hong Kong ${ }^{2}$ and London (Essex Court Chambers) and teaching at the School of Oriental and African Studies (SOAS) in London, where he became Professor of Chinese Law in 1995. His approach to legal analysis was mainly doctrinal, infused with a keen appreciation also of the cultural dimensions of Chinese law. His work, both academic and professional, also often touched on questions of public and private international law.

In his analysis of law in the People's Republic of China (PRC), Professor Dicks was concerned to understand the impact of both Chinese cultural traditions and socialist governance and ideology on the development of a socialist legal system. In his teaching and his research on modern Chinese law, he was interested in a wide range of questions, but was perhaps most concerned with developments and issues in the nature and interpretation of legislation in the mainland PRC.

His research work in this area was heralded by the appearance of an influential essay on the early evidence, found in newly drafted shipping legislation, of a slow legal recovery from the high points of political fervour in the Cultural Revolution. ${ }^{3}$ His interest later resulted in the subsequent publication of two fine essays on the nature and consequences of mainland China's approach to interpretation of statutory law. This approach is one in which administrative agencies play an important role, and the courts have limited powers, so that conflicts arise from time to time between judicial and administrative interpretations

* SOAS University of London, Email: mp@soas.ac.uk. This is a preliminary statement, and we welcome any information you might possess which would enable us to understand better the contributions of Professor Dicks.

1 A list of publications and related materials has been compiled by Michael Palmer and Xi Chao and is available as online supplementary material.

2 Chambers of Sir Oswald Cheung, followed by a move to St George's Building (where Professor Dicks was Head of the new chambers with Winston Poon, Hing Chun Wong and Gladys Li) and then to 2408 (later 2507) Edinburgh Tower. After returning to London in 1995, Professor Dicks remained in close touch with former colleagues and remained as a door tenant in the chambers of Ms Gladys Li SC until he ceased practice at the Bar in Hong Kong.

3 Dicks 1974. 
of the law. ${ }^{4}$ He was also concerned with mainland China's creation of a substantial legislative framework for commercial and investment law, including foreign trade and investment, maritime law ${ }^{5}$ banking law ${ }^{6}$ and civil law more generally. Other interests which his writings addressed were issues in the relationship between law and the maintenance of social order as complicated by factors such as relations between the Chinese Communist Party (CCP) and the state, the revival of legal institutions and institutionalized dispute processes, and administrative law and public accountability, in the post post-Mao era of economic reform. ${ }^{7} \mathrm{He}$ also wrote insightfully about the legal status of Macau and Hong Kong in relation to mainland China. ${ }^{8}$

In his analysis of the nature of Chinese customary law, which in Hong Kong is very important in a range of property and family matters, he argued convincingly that, despite local variations, there was not only an overall homogeneity in the system of customary law of late Imperial China, but also a remarkable degree of dovetailing between imperial statute law and local customary norms and practice. In the early 1970s, in his initial period of teaching at SOAS, he developed an impressive and comprehensive bibliography of customary Chinese law as it existed (and to some extent still exists) in mainland China and overseas Chinese communities in Hong Kong and South East Asia.

Professor Dicks also took the view that in imperial China the policies and laws of the Qing towards ethnic-religious groups such as Muslims and Buddhists were not, as might be thought, repressive in nature but rather in a number of respects quite liberal. ${ }^{9}$ In civil litigation in Hong Kong, Professor Dicks became the leading and much respected expert through his evidence in a number of important cases. These included, for example, the litigation concerning the estate of

4 Dicks 2000; 1995.

5 Dicks 1983a.

6 He was especially concerned with the role of banking law and administrative norms in China's planned economy, and although he did not publish a major study of this issue, his work on banking and economic planning was drawn on to good effect in his lectures on China's economic law.

7 See his general and very insightful account of the nature and trajectory of legal change in the PRC in Dicks 1989.

8 Dicks 1984; 1983b.

9 Dicks 2014a; 2013; 2012; 1990. In the latter essay, "New lamps for old: the evolving legal position of Islam in China, with special reference to family law," in which he drew for some of his material on the regulations of the imperial Chinese state's Li Fan Yuan ("Court of Colonial Affairs"), he observed that "the policy of the Qing emperors towards the Muslims in China proper did not explicitly admit of legal pluralism, but it seems to have been much less consistently oppressive than post-rebellion Muslim opinion would allow. A number of imperial edicts in the 18th century refer to the Muslims in essentially benevolent terms, drawing attention to their good qualities and the attainments of those promoted to high rank, while forbidding local officials to discriminate against them on various grounds and thus in effect giving them protection. In fact, provided that they did not offer a challenge to the authority of the Confucian state, it was an important strategy of Qing, government to refrain as far as possible from interfering directly in the lives of local communities. Despite the impressive semblance of uniformity suggested by the imperial codes and the hierarchy of local, provincial and national government, the fabric of the Chinese legal system was in some respects well-suited to harbour the growth of autonomous legal regimes within particular local communities" (p. 360). He was impressed by the manner in which the Li Fan Yuan conducted its business in legal matters such as, for example, formulating regulations for ethnic minority areas and the conflict of laws problems which occurred in the territories under its control, especially in criminal matters. 
Lau Wai Chau 劉維疇 which, among other issues, considered the question of whether a will could be used to create ancestral properties (Re Lau Wai Chau [2000] 3 HKCFAR 98). Professor Dicks also gave expert evidence in the long and protracted litigation regarding To 陶 lineage claims to the ownership of the Tsing Wan Kun temple in Castle Peak and the assets standing in the name of the temple (Secretary for Justice v To Kan Chi \& Ors [2000] 3 HKLRD 756). In Kan v Kan he advised the court on the rights of members in the dealing of Tso properties (Kan Fat-tat v Kan Yin-tat [1987] HKLR 516). And in the case concerning succession to the estate of Sung Chuen Pao, Professor Dicks advised the court on the status of concubines under the Republic of China Civil Code 1931 (Chan Chiu Lam \& Others v Yau Yee Ping [1998] HKLRD 716). Professor Dicks also gave evidence in the litigated dispute involving the management of the Tang Kwong Yu Tong 鄧光裕堂 and the nature of Tong property and finances, traditionally and in "modern" times (Tang Che Tai and others $\mathrm{v}$ Tang On Kwai HCA 331/2002). In Winfat Enterprises (HK) Ltd v Attorney General [1984] HKLR 32, Professor Dicks gave evidence on landholding in late imperial China. In these and other cases, in looking for evidence on a number of legal issues in such matters, Professor Dicks was willing to draw upon, where relevant, the jurisprudence of the $\mathrm{Da} \mathrm{Li}$ Yuan 大理院 and its successor, the Supreme Court of the Republic of China. This expertise proved invaluable also in his teaching on foundations of Chinese law and custom at SOAS. His vision of Chinese customary law and its place in the law and society of China is perhaps most clearly revealed in his short but important published review note on traditional Chinese statutory law and custom in Hong Kong and elsewhere. ${ }^{10}$

Professor Dicks practised extensively in commercial and civil law matters in Hong Kong, mainly as an advocate in litigation, appearing before the High Court and Court of Appeal. He was often involved also in cases as an arbitrator, and was nominated by the Securities and Futures Commission of the Hong Kong Government as an arbitrator for disputes arising out of the listings of Chinese companies on the Hong Kong Stock Exchange. He also served in some International Chamber of Commerce arbitrations.

Anthony Dicks studied law ${ }^{11}$ with distinction at both undergraduate and postgraduate level at Trinity College, Cambridge (1959 BA, 1960 LLB) and after completing his Current World Affairs Fellowship ${ }^{12}$ took appointments as a

10 Dicks 2014b.

11 Preceded by National Service in the Army (most probably 1955-57), stationed primarily in Iserlohn (North Rhine-Westphalia) Germany, where he became appreciative of (among other things) the local beer, Iserlohner Pilsner. Professor Martin Lau, a very good friend and close colleague of Professor Dicks at both the SOAS School of Law and Essex Court Chambers, advises that Professor Dicks had many fond memories of his time in Iserlohn.

12 This included two years at SOAS studying spoken and written Chinese, and where he met Henry McAleavy, a scholar of China who was held in high regard for his intellect, humour and passion for understanding a society and its historical experience through the eyes of its ordinary people. Professor Dicks appreciated McAleavy's very considerable strengths, and also writings on issues in traditional Chinese law. These essays, which strengthened or perhaps even initiated Professor Dicks's own 
law teacher at Trinity Hall (Fellow and Director of Studies in Law, and also Assistant Lecturer in the Faculty of Law and a member of the Faculty of Oriental Studies), and then SOAS. He was also appointed Research Fellow in Chinese Law at the British Institute of International and Comparative Law.

Called to the Bar in 1961, and admitted to the Hong Kong Bar in 1965, he practised full time in Hong Kong from the mid-1970s until returning to London in 1995, where he was a member of Essex Court Chambers. He became a QC in Hong Kong in 1994 (Senior Counsel, 1997). He was Professor of Chinese Law at SOAS from 1995 to 2002 (including a period as Head of Department) and following his retirement in 2002 he was appointed Emeritus Professor. At SOAS, Professor Dicks was responsible for a number of innovations in curriculum design, and important in helping to design and secure external funding for several substantial research projects, as well as assisting with the Lord Chancellor's Training Scheme for Young Chinese Judges. He continued to lend his support to the Law School in various ways after retirement, and also served for many years on the Editorial Board of The China Quarterly at SOAS.

Outside of SOAS, he made a number of important public service contributions. For example, he was a member of the Executive Council of the Universities' China Committee in London for several extended periods of time, and also was joint editor of the monograph series "Law in East Asia" (Wildy, Simmonds and Hill). He was a dedicated teacher and dissertation supervisor, ${ }^{13}$ and continued to teach as a visiting professor at Ca' Foscari University of Venice, until a few years before his death. He contributed to the official Hong Kong Government report on "Legal and Procedural Arrangements between Hong Kong and Mainland China" (1992). This important document laid out possible solutions to the civil and commercial legal questions likely to arise with the reversion of Hong Kong to the People's Republic in 1997.14 Also in the early 1990s, he was a member of the official delegation, led by Lord Howe, which visited the PRC as part of efforts to explore issues in - and exchange ideas with the Chinese authorities on - the observance of human rights and fundamental freedoms. ${ }^{15} \mathrm{He}$ also assisted in the planning of the new law school at the Chinese University of Hong Kong. Wherever and whenever he

\section{footnote continued}

interest in Chinese customary law, included McAleavy 1955; 1958a; 1958b; 1963; 1968. Later, while in Hong Kong, Professor Dicks became friends with Marinus J Meijer, a scholar who served as a diplomat in the Dutch Foreign Service for many years, including for a period in Hong Kong, and who conducted research, into Chinese family and criminal law as well as other specialized topics such as slavery, homosexuality and so on. Meijer's (1991) work on his final book, Murder and Adultery in late imperial China: a study of law and morality, was assisted by a presentation of some of his findings at a seminar held at the SOAS Law School, which Professor Dicks kindly arranged.

13 His students included Professor Carol Tan, current head of the SOAS Law School.

14 Dicks 1992.

15 Report of the Visit to China by the Delegation led by Lord Howe of Aberavon (1993) HMSO. 
was involved in such work, he made friends and was respected immensely for his erudition and kindness.

During his first extended stay in Hong Kong, Anthony met Victoria Mayne, who was working at the Universities Services Centre where he was conducting research. They married in Hong Kong in August 1969, and when Anthony fell seriously ill several years ago, Vicki was a source of devoted help and support. They enjoyed nearly 50 years of marriage.

In his academic, professional and personal life, Anthony's humanity - not least the collegial spirit he always displayed - was universally appreciated, as were his learned contributions to legal practice and legal studies. He (and Vicki) enjoyed a wide circle of friends, many of whom many of whom have commented on how their spirits were lifted whenever they met "the Dicks." When news of Anthony's death spread, many of these friends sent admiring and moving tributes, indicating how much they had enjoyed their friendship with Anthony, and how much they had learned from him.

Anthony is survived by Vicki, his two sisters, a brother, ${ }^{16}$ four nephews, three nieces, nine great-nephews and great-nieces, and a great-great nephew.

\section{Biographical note}

Michael PALMER is Professor Emeritus of Law at SOAS University of London. He is co-editor of the Journal of Comparative Law and editor of Amicus Curiae.

\section{Supplementary material}

Supplementary material is available online at https://doi.org/10.1017/ S0305741019001395.

\section{References}

Dicks, Anthony R. 1974. "A new model for Chinese legislation: the 1972 shipping regulations." The China Quarterly 57, 63-83.

Dicks, Anthony R. 1983a. "Some problems of maritime law." In Jerome Alan Cohen (ed.), Legal Aspects of Doing Business in China. New York: Practising Law Institute, 331-371.

Dicks, Anthony R. 1983b. "Treaty, grant, usage or sufferance: some legal aspects of the status of Hong Kong.” (Hong Kong Briefing.) The China Quarterly 95, 427-455.

Dicks, Anthony R. 1984. "Macao: legal fiction and gunboat diplomacy." In Goran Aijmer (ed.), Leadership on the China Coast. Copenhagen: Scandinavian Institute of Asian Studies.

Dicks, Anthony R. 1989. "The Chinese legal system: reforms in the balance." (The People's Republic of China After 40 Years.) The China Quarterly 119, 540-576.

Dicks, Anthony R. 1990. "New lamps for old: the evolving legal position of Islam in China, with special reference to family law." In Chibli Mallat and Jane Connors (eds.), Islamic Family Law. Bristol: Graham \& Trotman.

16 Mr. Adrian Dicks very kindly provided a note on Professor Dicks's life and career that has been most helpful in preparing this obituary. 
Dicks, Anthony R. 1992. "Negotiable and analogous instruments and other documents embodying payment obligations." Part XIV / Appendix to David M. Edwards CMG, JP (Chair) Report of the Working Party on Legal and Procedural Arrangements Between Hong Kong and China in Civil and Commercial Matters, Hong Kong, 13 October.

Dicks, Anthony R. 1995. "Compartmentalized law and judicial restraint: an inductive view of some jurisdictional barriers to reform." Special issue on "China's Legal reforms," guest-edited by Stanley Lubman. The China Quarterly 141, 82-109.

Dicks, Anthony R. 2000. "The law-making functions of the Chinese judiciary: filling holes in the civil law." In Ian Edge (ed.), Comparative Law in Global Perspective. Ardsley, NY: Transnational Publishers.

Dicks, Anthony R. 2012. "The ownership of Buddhist temples and the civil status of the clergy in China.” In C. Bulfoni (ed.), Tradizioni Religiose e Trasformazioni dell' Asia Contemporanea (Religious traditions and social transformations in contemporary Asia). Rome: Ambrosiana \& Bulzoni.

Dicks, Anthony R. 2013. "Introduction." La Famigli Nelle Culture e Nella Societa Dell 'Asia (Family in Asian Cultures and Societies). Rome: Ambrosiana \& Bulzoni.

Dicks, Anthony R. 2014a. "Buddhism and law in China: Qing Dynasty to the present." In Rebecca Redwood French and Mark A. Nathan (eds.), Buddhism and Law: An Introduction. Cambridge: Cambridge University Press, 234-253 (Chapter 13).

Dicks, Anthony R. 2014b. "Review of custom, land and livelihood in rural south China: the traditional land law of Hong Kong's New Territories, 1750-1950 by Patrick H. Hase." Journal of the Royal Asiatic Society Hong Kong Branch 54, 231-234.

McAleavy, Henry. 1955. "Certain aspects of Chinese customary law in the light of Japanese scholarship." Bulletin of the School of Oriental and African Studies 17 (3), 535-547.

McAleavy, Henry. 1958a. "Dien in China and Vietnam." Journal of Asian Studies 17 (3), 403-415.

McAleavy, Henry. 1958b. "Varieties of Hu'o'ng-Hỏa (香火): a problem of Vietnamese law." Bulletin of the School of Oriental and African Studies 21 (3), 608-619.

McAleavy, Henry. 1963. "Chinese law in Hong Kong: the choice of sources." In James Norman Dalrymple Anderson (ed.), Changing Law in Developing Countries. London: Allen \& Unwin.

McAleavy, Henry. 1968. "Chinese law.” In J. Duncan M. Derrett (ed.), An Introduction to Legal Systems. London: Sweet and Maxwell.

Meijer, Marinus J. 1991. Murder and Adultery in Late Imperial China: A Study of Law and Morality. Leiden \& New York: Brill. 